\section{Standardisation of myositis-specific antibodies: where are we today?}

With interest we read the recent article by Espinosa-Ortega et $a l^{1}$ comparing a line immunoassay (LIA) and immunoprecipitation (IP) for the detection of autoantibodies associated with idiopathic inflammatory myopathies (IIM). Historically, most of the clinical associations of myositis specific antibodies (MSAs) and myositis associated antibodies (MAAs) have been established using IP. Consequently, it is important to compare newer technologies such as LIA and dot blots (DB) to IP, which does not imply that IP is correct in all instances or that IP should be regarded as the 'gold standard'.

In a recent study that compared LIA and IP, poor agreement was found for several MSAs. ${ }^{2}$ In the letter by Espinosa-Ortega et al, the authors made a similar analysis, comparing IP and LIA in a cohort of 110 patients with IIM. For the LIA, the study also included controls $(n=60)$. A strength of the study is the use of both protein and RNA IP performed in a reference centre for IP. In the interest of assay evaluation and standardisation, it is valuable to provide data showing a more statistics-based approach for method comparison. Due to the rarity of several of the MSAs, large cohorts with thousands of patients are needed to carefully validate the positive agreement between methods. The small number of positive samples results in large 95\% CIs (table 1), which makes it difficult to draw true conclusions from the results. For example, in the article of Espinosa-Ortega et al, the 95\% CI derived from Kappa statistics for anti-TIF1 $\gamma$ ranged from 0.29 (poor) to 0.83 (excellent). Table 1 summarises the results obtained by Espinosa-Ortega et al ${ }^{1}$, Cavazzana et $a l^{2}$ and Mahler et al. 4

In addition, several interesting observations merit further discussion. First, the observation that anti-Mi-2 antibodies do not reflect the known clinical phenotype with skin involvement is interesting and might be related to the assay used. In two recent studies it has been demonstrated that the prevalence of anti-Mi-2 antibodies in polymyositis might be assay dependent. ${ }^{34}$ Second, for TIF1 $\gamma$ it is important to specify how positivity by IP is defined. The original description of anti-TIF1 $\gamma$ with IP reported a double band ( $\mathrm{p} 140 / \mathrm{p} 155)$, corresponding to TIF1 $\alpha$ $(140 \mathrm{kDa})$ and TIF1 $\gamma(155 \mathrm{kDa})$. Some laboratories might report both, as based on IP, or only anti-TIF $1 \gamma$, as based on either the $155 \mathrm{kDa}$ IP band or a secondary test. Most commercial in-vitro diagnostic assays, including LIAs, detect only anti-TIF1 $\gamma$, which might result in different results. While anti-TIF1 $\gamma$ is associated with cancer, anti-TIF1 $\alpha$ co-occurs with anti-TIF1 $\gamma$ and anti-Mi-2 autoantibodies. ${ }^{5}$ As a matter of fact, about $80 \%$ of patients with anti-Mi-2 antibodies also express anti-TIF1 $\alpha$ autoantibodies. ${ }^{5}$ In these patients the clinical phenotype matches the co-occurring MSA, rather than having a separate phenotype. In this context, it should be noted that there is a large variation in anti-TIF1 $\gamma$ reactivity between different LIA methods, with, for example, the Euroimmun LIA detecting more anti-TIF1 $\gamma$ reactivity than the Alphadia DB. ${ }^{6}$

Espinosa-Ortega et al emphasise the importance of anti-TIF1 $\gamma$ due to its association with cancer; however, other markers such as anti-MDA5 autoantibodies are equally important due to the association with rapidly progressive interstitial lung disease. In addition,

Table 1 Agreement between LIA and IP derived from three studies

\begin{tabular}{|c|c|c|c|c|c|}
\hline & Espinosa-Ortega et al & Cavazzana et al & Mahler et al & Combined & \\
\hline MSA & $\begin{array}{l}\text { DP/IP/LP/DN } \\
\text { Карра }(95 \% \text { CI) }\end{array}$ & & & & Interpretation (kappa) \\
\hline Jo-1 & $\begin{array}{l}11 / 1 / 7 / 91 \\
0.69(0.50 \text { to } 0.89)\end{array}$ & $\begin{array}{l}3 / 5 / 7 / 42 \\
0.21(-0.11 \text { to } 0.52)\end{array}$ & NA & $\begin{array}{l}14 / 6 / 14 / 133 \\
0.52(0.33 \text { to } 0.70)\end{array}$ & Minimal-Moderate \\
\hline TIF1y & $\begin{array}{l}1 / 2 / 0 / 107 \\
0.56(0.29 \text { to } 0.83)\end{array}$ & $\begin{array}{l}4 / 0 / 2 / 51 \\
0.78(0.49 \text { to } 1.00)\end{array}$ & $\begin{array}{l}11 / 4 / 4 / 138 \\
0.71(0.51 \text { to } 0.90)\end{array}$ & $\begin{array}{l}16 / 6 / 6 / 296 \\
0.71(0.55 \text { to } 0.86)\end{array}$ & Weak-Strong \\
\hline SRP & $\begin{array}{l}3 / 1 / 0 / 106 \\
0.85(0.57 \text { to } 1.00)\end{array}$ & $\begin{array}{l}0 / 3 / 7 / 47 \\
-0.08(-0.15 \text { to }-0.01)\end{array}$ & $\begin{array}{l}14 / 1 / 8 / 134 \\
0.73(0.56 \text { to } 0.89)\end{array}$ & $\begin{array}{l}17 / 5 / 15 / 287 \\
0.60(0.44 \text { to } 0.76)\end{array}$ & Weak-Moderate \\
\hline MDA5 & $\begin{array}{l}1 / 2 / 0 / 107 \\
0.49(-0.12 \text { to } 1.00)\end{array}$ & $\begin{array}{l}3 / 1 / 2 / 51 \\
0.64(0.26 \text { to } 1.00)\end{array}$ & $\begin{array}{l}14 / 1 / 5 / 137 \\
0.80(0.65 \text { to } 0.96)\end{array}$ & $\begin{array}{l}18 / 4 / 7 / 295 \\
0.75(0.61 \text { to } 0.89)\end{array}$ & Moderate-Strong \\
\hline $\mathrm{PM} / \mathrm{Scl}$ & $\begin{array}{l}2 / 3 / 1 / 104 \\
0.48(0.05 \text { to } 0.92)\end{array}$ & $\begin{array}{l}\text { NA } \\
\text { NA }\end{array}$ & $\begin{array}{l}\text { NA } \\
\text { NA }\end{array}$ & $\begin{array}{l}2 / 3 / 1 / 104 \\
0.48(0.05 \text { to } 0.92)\end{array}$ & NA \\
\hline $\mathrm{Ku}$ & $\begin{array}{l}3 / 0 / 1 / 106 \\
0.86(0.57 \text { to } 1.00)\end{array}$ & $\begin{array}{l}\text { NA } \\
\text { NA }\end{array}$ & $\begin{array}{l}\text { NA } \\
\text { NA }\end{array}$ & $\begin{array}{l}3 / 0 / 1 / 106 \\
0.86(0.57 \text { to } 1.00)\end{array}$ & NA \\
\hline SAE & $\begin{array}{l}3 / 0 / 1 / 106 \\
0.86(0.57 \text { to } 1.00)\end{array}$ & $\begin{array}{l}0 / 2 / 1 / 54 \\
-0.02(-0.06 \text { to } 0.01)\end{array}$ & $\begin{array}{l}15 / 0 / 3 / 139 \\
0.90(0.79 \text { to } 1.00)\end{array}$ & $\begin{array}{l}18 / 2 / 5 / 299 \\
0.83(0.70 \text { to } 0.95)\end{array}$ & $\begin{array}{l}\text { Moderate-Almost } \\
\text { perfect }\end{array}$ \\
\hline NXP2 & $\begin{array}{l}0 / 0 / 2 / 108 \\
0.00\end{array}$ & $\begin{array}{l}5 / 3 / 2 / 47 \\
-0.62(0.31 \text { to } 0.92)\end{array}$ & $\begin{array}{l}13 / 2 / 0 / 142 \\
0.92(0.81 \text { to } 1.00)\end{array}$ & $\begin{array}{l}18 / 5 / 4 / 297 \\
0.79(0.65 \text { to } 0.92)\end{array}$ & $\begin{array}{l}\text { Moderate-Almost } \\
\text { perfect }\end{array}$ \\
\hline $\mathrm{Mi}-2$ & $\begin{array}{l}2 / 0 / 6 / 102 \\
0.38(0.00 \text { to } 0.76)\end{array}$ & $\begin{array}{l}3 / 0 / 5 / 49 \\
0.51(0.45 \text { to } 0.87)\end{array}$ & $\begin{array}{l}12 / 3 / 9 / 133 \\
0.62(0.43 \text { to } 0.82)\end{array}$ & $\begin{array}{l}17 / 3 / 20 / 284 \\
0.56(0.41 \text { to } 0.72)\end{array}$ & Weak-Moderate \\
\hline EJ & $\begin{array}{l}0 / 0 / 0 / 110 \\
\text { NA }\end{array}$ & $\begin{array}{l}1 / 2 / 0 / 54 \\
0.49(-0.11 \text { to } 1.00)\end{array}$ & $\begin{array}{l}7 / 3 / 1 / 146 \\
0.76(0.54 \text { to } 0.99)\end{array}$ & $\begin{array}{l}8 / 5 / 1 / 310 \\
0.72(0.50 \text { to } 0.93)\end{array}$ & Weak-Almost perfect \\
\hline OJ & $\begin{array}{l}0 / 1 / 0 / 109 \\
0.00\end{array}$ & $\begin{array}{l}0 / 2 / 0 / 55 \\
0.00\end{array}$ & NA & $\begin{array}{l}\text { 0/3/0/164 } \\
\mathrm{NA}\end{array}$ & NA \\
\hline PL-7 & $\begin{array}{l}0 / 0 / 0 / 110 \\
\text { NA }\end{array}$ & $\begin{array}{l}0 / 0 / 2 / 55 \\
0.00\end{array}$ & $\begin{array}{l}12 / 3 / 0 / 142 \\
0.88(0.74 \text { to } 1.00)\end{array}$ & $\begin{array}{l}12 / 3 / 2 / 307 \\
0.82(0.67 \text { to } 0.97)\end{array}$ & $\begin{array}{l}\text { Moderate-Almost } \\
\text { perfect }\end{array}$ \\
\hline PL-12 & $\begin{array}{l}0 / 0 / 1 / 109 \\
0.00\end{array}$ & $\begin{array}{l}0 / 0 / 3 / 54 \\
0.00\end{array}$ & $\begin{array}{l}14 / 1 / 5 / 137 \\
0.80(0.65 \text { to } 0.96)\end{array}$ & $\begin{array}{l}14 / 1 / 9 / 300 \\
0.72(0.56 \text { to } 0.89)\end{array}$ & Weak-Strong \\
\hline
\end{tabular}

$95 \%$ Cls were reconstructed based on the given prevalence.

DN, double negative; DP, double positive; IP, Immunoprecipitation positive; LP, line immunoassay positive; MSA, myositis specific antibody. 


\begin{tabular}{|c|c|c|}
\hline MSA & Criticality/comment & Relevance/criticality \\
\hline HMGCoA reductase & $\begin{array}{l}\text { The presence of anti-HMGCR antibodies predicts poor response to corticosteroid and } \\
\text { immunosuppressant therapy. This anticipation is relevant for the clinician. }\end{array}$ & $\begin{array}{l}\text { Relevant, not critical; however, false negative might lead } \\
\text { to omission of biopsy }\end{array}$ \\
\hline TIF1y & $\begin{array}{l}\text { Strong association with malignancy in elderly patients. Extensive screening for malignancy } \\
\text { is necessary prior to treatment of IIM. }\end{array}$ & $\begin{array}{l}\text { Critical, false negative result might lead to delayed } \\
\text { diagnosis of cancer }\end{array}$ \\
\hline SRP & $\begin{array}{l}\text { Associated with severe treatment resistant myopathy, leading to long term } \\
\text { immunosuppressive therapy The presence of SRP antibodies predicts poor response } \\
\text { to corticosteroid and immunosuppressant therapy. This anticipation is relevant for the } \\
\text { clinician. }\end{array}$ & $\begin{array}{l}\text { Relevant, not critical; however, false negative might lead } \\
\text { to omission of biopsy }\end{array}$ \\
\hline MDA5 & $\begin{array}{l}\text { Positive result should trigger screening for ILD and if confirmed more aggressive treatment } \\
\text { and clinical vigilance }\end{array}$ & $\begin{array}{l}\text { Critical, False negative result may lead to less intensive } \\
\text { (respiratory) monitoring with a delay }\end{array}$ \\
\hline $\mathrm{PM} / \mathrm{SCl}$ & In general, associated with a milder disease course & Not critical, low relevance \\
\hline $\mathrm{Ku}$ & $\begin{array}{l}\text { Often associated with SLE and/or SSc. Requires monitoring and treatment to coexisting } \\
\text { SLE and/or SSc, especially when other antibodies are present (eg, anti-dsDNA). }{ }^{12}\end{array}$ & Relevant, not critical \\
\hline Mi-2 & $\begin{array}{l}\text { In general, associated with a milder disease course. If present without other MSA, } \\
\text { reassures relatively mild disease phenotype. }\end{array}$ & $\begin{array}{l}\text { Relevant, not critical; false positive can lead to a wrong } \\
\text { perception of milder disease (no monitoring for ILD) }\end{array}$ \\
\hline Jo-1, EJ, OJ, PL-7, PL-12 & $\begin{array}{l}\text { Positive result triggers the clinician to screen for ILD and to prospectively follow-up } \\
\text { pulmonary function; often requires long-term immunosuppressive treatment } \\
\text { Predicts better therapeutic response to rituximab } \\
\text { I3 } \\
\text { Influences patient management when pulmonologists identify these antibodies in } \\
\text { patients with unexplained ILD } \\
\text { Consider immunosuppressant strategies } \\
\text { Follow-up for appearance of extra-pulmonary manifestations of the antisynthetase } \\
\text { syndrome }{ }^{14}\end{array}$ & $\begin{array}{l}\text { Relevant, not critical; False negative results might have } \\
\text { a negative effect on optimal therapy choice in severe } \\
\text { myositis (more arguments for rituximab) and patients } \\
\text { with unexplained ILD (as single manifestation) might } \\
\text { experience delay in diagnosis. }\end{array}$ \\
\hline
\end{tabular}

DM, dermatomyositis; IIM, idiopathic inflammatory myopathies; ILD, interstitial lung disease; MSA, myositis specific antibodies; SLE, systemic lupus erythematosus; SSC, systemic sclerosis.

the consequences for false positive or false negative results can be different depending on the autoantibody (see table 2).

Similar to a previous study reporting variability between blot assays for anti-Jo-1 antibodies, ${ }^{6}$ the current letter also reports higher than expected variability for anti-Jo-1 antibodies which is related to the known limitation of IP for the detection of antiJo- 1 antibodies, due to the relatively thin uncharacteristic band in IP (in contrast to other aminoacyl-tRNA synthetases) and to the co-migration with the $\operatorname{IgG}$ heavy chain. ${ }^{7}$

IP analysis of RNA components to confirm the presence of tRNA is helpful; however, it does not reveal the tRNA identity; it only indicates IP of 'some' tRNA and cannot distinguish between histidyl-tRNA and other tRNAs. Practically, if a band corresponding to $\mathrm{a} \sim 50 \mathrm{kD}$ protein is observed on IP, and tRNA by RNA analysis is present, it is reasonable to report anti-Jo-1 antibody positivity. ${ }^{7}$ Seven out of 18 anti-Jo-1 positive samples, as detected by LIA were negative by IP. Three of them tested positive by a fluorescence enzyme immunoassay (FEIA), one borderline and one negative. It appears that IP misses true positive anti-Jo-1 samples that are detected by LIA and FEIA. This last observation is in line with the concept that IP should not be regarded as a gold standard in all instances. Although known and used for decades, IP is by no means standardised across different laboratories which can lead to significant variability. Consequently, site to site comparison studies for IP are needed, followed by a standardisation approach.

As pointed out above, the rarity of several of the MSAs requires large cohorts with thousands of patients in order to carefully validate agreement (especially positive per cent agreement) between methods. A viable and more realistic approach is to select positive samples from clinically well-characterised patients and complement those with also well characterised controls and test this cohort with various methods and platforms, including IP and LIA. Although this introduces a biassed inclusion criterion, it might provide more meaningful data. Along those lines, a close collaboration between clinicians, patient groups, research networks and kit manufacturers are mandatory to make serum samples available for validation, calibration and quality control. An alternative approach for calibration and quality control is the generation of human or humanised monoclonal antibodies. Standardisation is imperative for the consideration of additional MSAs (in addition to anti-Jo-1) as part of future classification criteria for IIM. ${ }^{8-10}$ To conclude, we thank the authors for conducting this study and encourage future studies with larger patient cohorts (such as MyoNet/EuroMyositis), ideally including different novel methods for the detection of MSA next to IP. ${ }^{11}$

\footnotetext{
Michael Mahler, ${ }_{1}^{\oplus 1}$ Jean-Baptiste Vulsteke, ${ }^{2,3}$ Xavier Bossuyt, ${ }^{\oplus, 5}$ Ellen De Langhe, ${ }^{2,3}$ Minoru Satoh ${ }^{6}$

${ }^{1}$ Research and Development, Inova Diagnostics, San Diego, California, USA ${ }^{2}$ Laboratory of Tissue Homeostasis and Disease, Skeletal Biology and Engineering Research Center, Department of Development and Regeneration, KU Leuven, Leuven, Belgium

${ }^{3}$ Division of Rheumatology, University Hospitals Leuven, Leuven, Belgium

${ }^{4}$ Clinical and Diagnostic Immunology, Department of Microbiology, Immunology and Transplantation, KU Leuven, Leuven, Belgium

${ }^{5}$ Department of Laboratory Medicine, University Hospitals Leuven, Leuven, Belgium ${ }^{6}$ Department of Clinical Nursing, University of Occupational and Environmental Health, Kitakyushu, Japan
}

Correspondence to Dr Michael Mahler, Research, INOVA Diagnostics, San Diego, CA 92131, USA; mmahler@inovadx.com

Contributors All authors contributed to the correspondence. 
Funding The authors have not declared a specific grant for this research from any funding agency in the public, commercial or not-for-profit sectors.

Competing interests MM is employee of Inova Diagnostics. However, no product of the company is mentioned in the correspondence.

Patient consent for publication Not required.

Provenance and peer review Not commissioned; internally peer reviewed.

(c) Author(s) (or their employer(s)) 2019. No commercial re-use. See rights and permissions. Published by BMJ.

\section{Check for updates}

To cite Mahler M, Vulsteke J-B, Bossuyt $\mathrm{X}$, et al. Ann Rheum Dis Epub ahead of print: [please include Day Month Year]. doi:10.1136/annrheumdis-2019-216003

Received 8 July 2019

Accepted 10 July 2019

Ann Rheum Dis 2019;0:1-3. doi:10.1136/annrheumdis-2019-216003

\section{REFERENCES}

1 Espinosa-Ortega F, Holmqvist M, Alexanderson $\mathrm{H}$, et al. Comparison of autoantibody specificities tested by a line blot assay and immunoprecipitation-based algorithm in patients with idiopathic inflammatory myopathies. Ann Rheum Dis 2019.

2 Cavazzana I, Fredi M, Ceribelli A, et al. Testing for myositis specific autoantibodies: comparison between line blot and immunoprecipitation assays in 57 myositis sera. J Immunol Methods 2016;433:1-5.

3 Richards M, García-De La Torre I, González-Bello YC, et al. Autoantibodies to $\mathrm{Mi}-2$ alpha and $\mathrm{Mi}-2$ beta in patients with idiopathic inflammatory myopathy. Rheumatology 2019;14.
4 Mahler M, Betteridge Z, Bentow C, et al. Comparison of three immunoassays for the detection of myositis specific antibodies. Front Immunol 2019;10:848.

5 Muro Y, Ishikawa A, Sugiura K, et al. Clinical features of anti-TIF1- $\alpha$ antibody-positive dermatomyositis patients are closely associated with coexistent dermatomyositisspecific autoantibodies and anti-TIF1- $\gamma$ or anti-Mi-2 autoantibodies. Rheumatology 2012;51:1508-13.

6 Vulsteke J-B, De Langhe E, Claeys KG, et al. Detection of myositis-specific antibodies. Ann Rheum Dis 2019;78:e7.

7 Satoh M, Tanaka S, Ceribelli A, et al. A comprehensive overview on myositis-specific antibodies: new and old biomarkers in idiopathic inflammatory myopathy. Clin Rev Allergy Immunol 2017;52:1-19.

8 Lundberg IE, Bottai M, Tjärnlund A. Response to: 'Performance of the 2017 European League Against Rheumatism/American College of Rheumatology classification criteria for adult and juvenile idiopathic inflammatory myopathies in clinical practice' by Hočevar et al. Ann Rheum Dis 2018;77:e91.

9 Malaviya AN. 2017 EULAR/ACR classification criteria for adult and juvenile idiopathic inflammatory myopathies and their major subgroups: little emphasis on autoantibodies, why? Ann Rheum Dis 2018;77:e77.

10 Vulsteke J-B, De Langhe E, Mahler M. Autoantibodies at the Center of (sub) Classification-Issues of Detection. JAMA Neurol 2019;76:867.

11 Lilleker JB, Vencovsky J, Wang G, et al. The EuroMyositis registry: an international collaborative tool to facilitate myositis research. Ann Rheum Dis 2018;77:30-9.

12 SpielmannL, NespolaB, SeveracF. Anti-Ku syndrome with elevated CK and anti-Ku syndrome with anti-dsDNA are two distinct entities with different outcomes. Ann Rheum Dis 2019.

13 Aggarwal R, Bandos A, Reed AM, et al. Predictors of clinical improvement in rituximab-treated refractory adult and juvenile dermatomyositis and adult polymyositis. Arthritis Rheumatol 2014;66:740-9.

14 Mahler M, Miller FW, Fritzler MJ. Idiopathic inflammatory myopathies and the antisynthetase syndrome: a comprehensive review. Autoimmun Rev 2014;13:367-71. 